\section{Effect of Low Levels of Ethylene on Sprouting of Potatoes in Storage}

\author{
R.B.H. Wills and M.A. Warton \\ School of Applied Sciences, University of Newcastle, P.O. Box 127, Ourimbah, \\ NSW 2258, Australia
}

\author{
J.K. Kim \\ Department of Food Science and Nutrition, Sangju National University, \\ Sangju, Korea
}

Additional index words. Solanum tuberosum, postharvest

\begin{abstract}
Potato tubers (Solanum tuberosum cv. Sebago) were stored at $20{ }^{\circ} \mathrm{C}$ in air containing ethylene at $\left\langle 0.005,0.01,0.1,1.0\right.$, or $10 \mu \mathrm{L} \cdot \mathrm{L}^{-1}$ and the level of sprouting was measured over 35 days. The time for tubers to develop an average of one sprout per tuber was found to linearly increase as the $\log _{10}$ ethylene concentration decreased with the effect present over the whole range of concentration. After 35 days of storage, the number of sprouts/tuber was inversely related to the ethylene concentration, but the weight of sprouts was only lower for tubers held in $<0.005 \mu \mathrm{L} \cdot \mathrm{L}^{-1}$ ethylene. The more numerous sprouts on tubers held in $10 \mu \mathrm{L} \cdot \mathrm{L}^{-1}$ ethylene were short and thick, while the less numerous sprouts on tubers in $0.01-1.0 \mu \mathrm{L} \cdot \mathrm{L}^{-1}$ were long, thin, and branched, and resulted in no significant difference in total sprout weight between these concentrations. Reducing the concentration of ethylene in the atmosphere around stored potatoes thus reduced sprouting, but levels $<0.01 \mu \mathrm{L} \cdot \mathrm{L}^{-1}$ are required to minimize both sprout emergence and sprout growth.
\end{abstract}

Potato (Solanum tuberosum L.) tubers can be stored for long periods before use for table consumption or processing into a wide range of products. Common postharvest treatments of potatoes are curing to stimulate periderm formation in order to promote wound healing and thereby reduce susceptibility to rotting and transpiration, followed by storage at 4 to 20 ${ }^{\circ} \mathrm{C}$ to inhibit sprouting (Jadhav and Kadam, 1998). Ethylene is well known to promote a wide range of senescent reactions in horticultural produce. Potatoes are reported to have a low rate of production of ethylene of $<0.1$ $\mu \mathrm{L} \cdot \mathrm{kg}^{-1} \cdot \mathrm{h}^{-1}$ (Knee et al., 1985) and a moderate sensitivity to ethylene exposure (Schouten, 1985). Ethylene has been reported to promote respiration of potatoes (Reid and Pratt, 1972) with the increase in respiration directly related to the concentration of applied ethylene (Rylski et al., 1974). There are varied reports of the effect of ethylene on potato sprouting. Rylski et al. (1974) cite early work in the 1920 s by Denny reporting that short term exposure to ethylene at $10^{3}$ and $10^{4} \mu \mathrm{L} \cdot \mathrm{L}^{-1}$ for $4-7 \mathrm{~d}$ had no effect on sprouting and by Vacha and Harvey (1927) reporting exposure to $10^{3} \mu \mathrm{L} \cdot \mathrm{L}^{-1}$ for 6 $\mathrm{d}$ stimulated sprouting and increased sprout growth. The only reported study with low concentrations of ethylene was by Rylski et al. (1974) who found that exposure for $72 \mathrm{~h}$ to atmospheres containing ethylene at 0.02 to $20 \mu \mathrm{L} \cdot \mathrm{L}^{-1}$ stimulated sprouting but sprout elongation was inhibited compared to untreated tubers. In commercial storage, potatoes could be exposed to ethylene for a considerable period. Rosa (1928) exposed potatoes to 455 or $2500 \mu \mathrm{L} \cdot \mathrm{L}^{-1}$ for 2,3 , and 4

Received for publication 15 Aug. 2002. Accepted for publication $25 \mathrm{Feb} .2003$. weeks and found sprouting was inhibited after the 2- and 3-week treatments, but promoted after the 4-week treatment. Rylski et al. (1974) found sprouting was inhibited by prolonged exposure to $2 \mu \mathrm{L} \cdot \mathrm{L}^{-1}$ ethylene. No studies have been reported for prolonged exposure of potatoes to ethylene at $<1 \mu \mathrm{L} \cdot \mathrm{L}^{-1}$, a level more likely to be encountered in commercial storage; ethylene at $0.04 \mu \mathrm{L} \cdot \mathrm{L}^{-1}$ was found inside stacks of potato cartons held in the Sydney wholesale markets (V.V.V. Ku and R.B.H. Wills, unpublished data). This study examined the sprouting of potatoes during prolonged exposure to ethylene at concentrations in the range $<0.005$ to $10 \mu \mathrm{L} \cdot \mathrm{L}^{-1}$.

\section{Materials and Methods}

Unstored potatoes (cv. Sebago) were obtained from the Sydney wholesale markets. Blemish-free tubers of uniform size were randomly allocated into 15 groups of four tubers, with each group comprising a treatment unit. The treatment units were placed into separate 4-L plastic containers and three containers exposed to each of five concentrations of ethylene. The experiment was replicated with tubers purchased on three occasions. Air containing ethylene at $0.01,0.1,1.0$, or $10 \mu \mathrm{L} \cdot \mathrm{L}^{-1}$ was obtained by the controlled mixing of cylinder ethylene at $0.1 \mathrm{~mL} \cdot \mathrm{L}^{-1}$ (BOC Gases, Sydney) with ambient air that had been humidified by bubbling through water. Ethylene-free air was obtained by passing ambient air through a tube containing alumina impregnated with potassium permanganate (Circulaire, Montreal) and was then humdified. A sample $(1 \mathrm{~mL})$ of each gas mixture was collected in a syringe and the ethylene concentration determined by flame ionisation gas chromatography (Series
580 Gow-Mac, Bridgewater, N.J.) fitted with a stainless steel column $(180 \times 0.3 \mathrm{~cm})$ packed with activated alumina ( $80-100$ mesh) (Alltech, Sydney) and operating conditions of column temperature $110{ }^{\circ} \mathrm{C}$, injector and detector temperature $150^{\circ} \mathrm{C}$, nitrogen carrier gas flow rate $30 \mathrm{~mL} \cdot \mathrm{min}^{-1}$, hydrogen flow rate $30 \mathrm{~mL} \cdot \mathrm{min}^{-1}$ and air flow rate $300 \mathrm{~mL} \cdot \mathrm{min}^{-1}$. Ethylene was quantified by comparison of the peak height with that obtained for a standard gas mixture containing $0.16 \pm 0.05 \mu \mathrm{L} \cdot \mathrm{L}^{-1}$ (BOC Gases, Sydney). The concentration of the ethylene-free air was designated as $<0.005$ $\mu \mathrm{L} \cdot \mathrm{L}^{-1}$, the limit of detection of the analytical method. The gas mixtures were passed through the containers holding the potato tubers at $20 \mathrm{~L} \cdot \mathrm{h}^{-1}$. The flow rate was selected from preliminary trials that showed the outlet air always contained $<0.5 \%$ carbon dioxide. The ventilated potatoes were stored at $20^{\circ} \mathrm{C}$ and assessed twice weekly for the presence of sprouting; a sprout was considered as any growth from an eye that was longer than 0.2 $\mathrm{mm}$. The number of sprouts per tuber was noted at each observation. After $35 \mathrm{~d}$, all sprouts were removed, weighed, and calculated as a percentage of the final potato weight. The postharvest life was considered to end when an average of one sprout per tuber was present in a treatment unit.

\section{Results and Discussion}

The time for potato tubers to develop one sprout per tuber (i.e., the postharvest life) increased as the concentration of ethylene in the atmosphere increased with the effect being more pronounced at the lower end of the ethylene range (Table 1). The data fitted a linear regression $y=-2.5 x+23.0$, where $y$ $=$ postharvest life $(\mathrm{d})$ and $\mathrm{x}=\log _{10}$ ethylene concentration $\left(\mu \mathrm{L} \cdot \mathrm{L}^{-1}\right)$, which was highly significant $(P<0.001)$. Table 2 shows that at the end of the storage period of $35 \mathrm{~d}$, there was a lower number of sprouts on tubers as the ethylene concentration was reduced $(P<$ $0.001)$. The total weight of the sprouts was lower for tubers stored in $<0.005 \mathrm{~L} \cdot \mathrm{L}^{-1}$ ethylene, but there was no significant difference in the weight of sprouts on tubers in the other ethylene concentrations. The physical nature of the sprouts also changed with ethylene concentration. They were short and thick in $10 \mu \mathrm{L} \cdot \mathrm{L}^{-1}$, short and thin in $<0.005 \mu \mathrm{L} \cdot \mathrm{L}^{-1}$, while in $0.01-1.0 \mu \mathrm{L} \cdot \mathrm{L}^{-1}$ ethylene sprouts

Table 1. Effect of ethylene on postharvest life of potatoes stored at $20^{\circ} \mathrm{C}$

\begin{tabular}{|c|c|}
\hline $\begin{array}{l}\text { Ethylene concn } \\
\left(\mu \mathrm{L} \cdot \mathrm{L}^{-1}\right)\end{array}$ & $\begin{array}{l}\text { Postharvest } \text { life }^{z} \\
\text { (d) }\end{array}$ \\
\hline$<0.005$ & $32.0 \mathrm{a}^{\mathrm{y}}$ \\
\hline 0.01 & $26.8 \mathrm{~b}$ \\
\hline 0.1 & $23.7 \mathrm{bc}$ \\
\hline 1.0 & $22.3 \mathrm{c}$ \\
\hline 10 & $22.3 \mathrm{c}$ \\
\hline \multicolumn{2}{|c|}{$\begin{array}{l}\text { zPostharvest life was the time taken for an } \\
\text { average of one sprout to develop on tubers in } \\
\text { a treatment unit. Each value is the mean of nine } \\
\text { groups of four tubers comprising three groups } \\
\text { obtained on each of three purchase dates. } \\
\text { y Mean separation by } \mathrm{LSD}_{0.05} \text {. }\end{array}$} \\
\hline
\end{tabular}


Table 2. Effect of ethylene on sprouting of potatoes ${ }^{\mathrm{z}}$ after $35 \mathrm{~d}$ storage at $20{ }^{\circ} \mathrm{C}$.

\begin{tabular}{lccc}
\hline $\begin{array}{l}\text { Ethylene concn } \\
\left(\mu \mathrm{L} \cdot \mathrm{L}^{-1}\right)\end{array}$ & $\begin{array}{c}\text { Sprout incidence } \\
\text { (no./tuber) }\end{array}$ & $\begin{array}{c}\text { Sprout wt } \\
(\mathrm{g} / 100 \mathrm{~g})\end{array}$ & $\begin{array}{c}\text { Sprout } \\
\text { description }\end{array}$ \\
\hline$<0.005$ & $1.2 \mathrm{a}^{y}$ & $0.08 \mathrm{a}^{y}$ & short thin \\
0.01 & $2.3 \mathrm{~b}$ & $0.31 \mathrm{~b}$ & long thin branched \\
0.1 & $3.6 \mathrm{c}$ & $0.38 \mathrm{~b}$ & long thin branched \\
1.0 & $4.7 \mathrm{~d}$ & $0.34 \mathrm{~b}$ & long thin branched \\
10 & $5.0 \mathrm{~d}$ & $0.27 \mathrm{~b}$ & short thick \\
\hline
\end{tabular}

${ }^{2}$ Each value is the mean of nine groups of four tubers comprising three groups obtained on each of three purchase dates.

${ }^{\mathrm{y}}$ Mean separation within columns by $\mathrm{LSD}_{0.05}$.

were thin and branched and of greater length as the ethylene concentration decreased. For the $0.01-1.0 \mu \mathrm{L} \cdot \mathrm{L}^{-1}$ concentration range, the inverse association between longer sprouts and a smaller number of sprouts resulted in no significant difference in total sprout weight. Thus, in this concentration range, increasing ethylene inhibits sprout formation but promotes elongation once sprouts emerge. It is concluded that the atmosphere in potato storage rooms will need to contain ethylene at $<0.01 \mu \mathrm{L} \cdot \mathrm{L}^{-1}$ to avoid stimulation of both sprout emergence and growth.

\section{Literature Cited}

Jadhav, S.J. and S.S. Kadam. 1998. Potato, p. 1169. In: D.K. Salunkhe and S.S. Kadam (eds.).
Handbook of vegetable science and technology: Production, composition, storage and processing. Marcel Dekker, New York.

Knee M., F.J. Proctor, and C.J. Dover. 1985 The technology of ethylene control: Use and removal in post-harvest handling of horticultural commodities. Ann. Applied Biol. 107:581-595.

Reid, M.S. and H.K. Pratt. 1972. Effects of ethylene on potato tuber respiration. Plant Physiol. 49: 252-255.

Rylski, I., L. Rapport, and H.K. Pratt. 1974. Dual effects of ethylene on potato dormancy and sprout growth. Plant Physiol. 53:658-662.

Rosa, J.T. 1928. Effects of chemical treatments on dormant potato tubers. Hilgardia 3:125-142.

Schouten, S.P. 1985. Significance of ethylene in postharvest handling of vegetables. In: J.A. Tucker and G.A. Roberts (eds.). Ethylene and plant development. Butterworths, London.

Vacha, G.A. and R.B. Harvey. 1927. The use of ethylene, propylene and similar compounds in breaking the rest period of tubers, bulbs, cuttings and seeds. Plant Physiol. 2:187-193. 